\title{
Analisis Laporan Keuangan Berdasarkan Rasio Likuiditas Pada PT. Bank Perkreditan Rakyat Batang Kapas
}

\author{
Ilvi Cintia ${ }^{1)}$, Doni Marlius ${ }^{2)}$ \\ 1.2) Akademi Keuangan dan Perbankan "Pembangunan" Padang \\ ilvicintia123@gmail.com
}

\begin{abstract}
This study was conducted to determine the level of profitability in PT. BPR Batang Kapas which includes Cash Ratio (CR), Quick Ratio (QR) and Loan to Deposit Ratio $(L D R)$. This research is quantitative, where this quantitative method analyzes the calculation of the liquidity ratio at PT. BPR Batang Kapas. This study uses the financial statements of PT. BPR Batang Kapas for the 2017-2019 financial year. The type of data used is secondary data in the form of company financial performance data which includes data on Chas Ratio (CR), Quick Ratio (QR) and Loan to Deposit Ratio (LDR). Where the Cash Ratio (CR) of PT. BPR Batang Kapasin 2017-2019 is in a healthy position, namely at $>=4,05 \%$ position. For Quick Ratio $(Q R) P T$. BPR Batang Kapas in 2017-2019 are in a healthy position or it can be said that the bank is able to bear its short-term burden with criteria $>100 \%$. While for Loan to Deposit Ratio (LDR) PT. BPR Batang Kapas 2017 and 2018 the bank is said to be healthy, because it is in a 75\% < LDR $\leq 85 \%$, but in 2019 it shows that the bank is said to be quite healthy, because it is in the $85 \%<L D R \leq 100 \%$ position.
\end{abstract}

Keyword : Liquidity,Cash Ratio (CR), Quick Ratio (QR) and Loan to Deposit (LDR)

\section{LATAR BELAKANG}

Kondisi perbankan di Indonesia pada saat pandemi ini banyak menghadapi tantangan seperti kredit macet dan juga berdampak pada pertumbuhan ekonomi masyarakat. Kredit macet ini di akibatkan karena nasabah kesulitan dalam memenuhi kewajibannya untuk membayar kredit di tengah kondisi pandemi yang mengakibatkan ekonomi nasabah menurun drastis. Akibat kredit macet ini perbankan kesulitan dalam likuiditasnya, diharapkan agar bank dapat menjaga likuiditas banknya dengan baik.

Likuiditas yaitu kebijakan perusahaan dalam memenuhi tanggung jawab keuangannya pada waktu yang telah ditentukan. Menurut Eviani (2015) yaitu kebijakan perusahaan dalam melaksanakan pembayaran kewajiban-kewajiban yang segera dipenuhi, kewajiban yang dimaksud bersifat jangka pendek. Menurut Umur RI Nomor 10 Tahun 1998 Bank yaitu badan usaha yang menampung dana dari masyarakat dalam bentuk simpanan dan menyalurkannya dalam bentuk kredit atau bentuk-bentuk lainnya dalam rangka mengembangkan taraf hidup rakyat banyak. 
Dalam Undang-Undang RI No. 10 Tahun 1998 tentang perbankan, menurut jenisnya bank terdiri dari Bank Umum dan Bank Perkreditan Rakyat (BPR).

Bank Umum merupakan bank yang melakukan kegiatan usaha secara konvensional dan atau berdasarkan prinsip syariah yang dalam kegiatannya menerima jasa lalu lintas pembayaran. Sementara itu Bank Perkreditan Rakyat (BPR) merupakan bank yang melakukan pekerjaan usaha secara konvensional atau berdasarkan prinsip syariah dalam kegiatannya tidak menerima jasa lalu lintas pembayaran.

BPR telah tumbuh dan berkembang sebagai lembaga kecil di masyarakat yang memberikan jasa pelayanan kepada usaha mikro kecil dan menengah karena BPR ditujukan untuk melayani usaha-usaha kecil. Agar dapat melakukan tugas pokok dan mempertahankan kelangsungan BPR kepercayaan masyarakat sangat penting. Untuk menerima gambaran tentang kemajuan finansial suatu bank, perlu mengadakan analisis atau interpretasi mengenai finansial dari bank yang bersangkutan, dimana data finansial itu tergambar di dalam laporan keuangan.

Laporan keuangan merupakan data-data yang sifatnya kuantitatif. Menurut Adlia Soma (2018) laporan keuangan pada dasarnya yaitu hasil dari proses akuntansi yang mampu digunakan sebagai alat untuk mengkomunikasikan data finansial atau kegiatan perusahaan bagi pihak-pihak yang bersangkutan dengan data. Dalam menganalisa dan mengukur posisi laporan finansial untuk memahami seberapa jauh keahlian bank. Dalam memenuhi tanggung jawabnya serta mengetahui potensi dan kemajuan suatu bank, maka faktor utama yang ditentukan adalah aspek likuiditas. Adapun laporan keuangan yang biasa dikenal yaitu neraca, laporan laba rugi atau hasil usaha, laporan perubahan ekuitas, laporan arus kas dan laporan posisi keuangan.

Salah satu BPR di Indonesia adalah PT. Bank Perkreditan Rakyat Batang Kapas. PT. Bank Perkreditan Rakyat Batang Kapas merupakan salah satu BPR yang berada di pesisir selatan kecamatan batang kapas. BPR ini harus memperhatikan tingkat likuiditasnya dalam membayar utang jangka pendeknya dengan menggunakan aktiva lancar yang dimiliki oleh bank tersebut.

Berikut data keuangan yang digunakan untuk mengetahui perkembangan likuiditas PT. BPR Batang Kapas periode 2017-2019.

\section{Tabel 1}

Data Keuangan PT. BPR Batang Kapas

Periode 2017-2019

\begin{tabular}{cccc}
\hline Keterangan & $\mathbf{2 0 1 7}$ & $\mathbf{2 0 1 8}$ & $\mathbf{2 0 1 9}$ \\
\hline Cash Ratio & $33,36 \%$ & $32,78 \%$ & $23,84 \%$ \\
Quick Ratio & $1.626,11 \%$ & $2.185,18 \%$ & $646,25 \%$ \\
Loan to Deposit & $77,42 \%$ & $77,01 \%$ & $86 \%$ \\
Ratio & & & \\
\hline
\end{tabular}

Sumber : Laporan Keuangan PT. BPR Batang Kapas

PT. Bank Perkreditan Rakyat Batang Kapas dalam hal ini neraca perusahannya dalam posisi likuiditas mengalami fluktuasi, ini bisa dilihat dari tiga 
indikator rasio likuiditas yaitu Cash Ratio, Quick Ratio dan Loan to Deposit ratio. $C R$ pada tahun 2017 nilai $C R$ sebesar 33,36\% tergolong sehat karena besar dari 4,05\%, dan pada tahun 2018 sebesar $32,78 \%$ turun sebesar $0,58 \%$ tergolong sehat. $Q R$ pada tahun 2017 memiliki nilai sebesar 1.626,11\%, dikatakan baik karena berada pada posisi $>100 \%$. Dan pada tahun 2018 mengalami kenaikan sebesar 2.185,18\% dan tahun 2019 mengalami penurunan sebesar 646,25\%. Untuk LDR pada tahun 2017 nilai $L D R$ sebesar 77,42\% dan tahun 2018 sebesar 77,01\% tergolong sehat, karena berada pada posisi $75 \%<$ LDR $\leq 85 \%$. Dan pada tahun 2019 nilai $L D R$ sebesar $86 \%$ tergolong cukup sehat, karena berada pada posisi $85 \%<$ LDR $\leq 100 \%$ yang telah ditetapkan BI.

Untuk menentukan kebijakan-kebijakan yang diambil dalam mempertahankan posisi likuiditas yang sehat dengan tetap memenuhi kewajiban penyaluran dana dalam rangka menjaga kelangsungan operasional perusahaan, maka sangatlah penting untuk menilai rasio likuiditas bank tersebut. Menilai rasio likuiditas pada PT. BPR Batang Kapas dengan menggunakan beberapa rasio likuiditas yang lazim digunakan dalam suatu bank. Berdasarkan latar belakang diatas penulis tertarik untuk melakukan penelitian pada PT. BPR Batang Kapas dengan judul "Analisis Laporan Keuangan Berdasarkan Rasio Likuiditas Pada PT. Bank Perkreditan Rakyat Batang Kapas". Berdasarkan uraian latar belakang tersebut, maka yang dibahas dalam tugas akhir ini yaitu tentang bagaimana rasio likuiditas pada PT. Bank Perkreditan Rakyat Batang Kapas.

\section{METODE PENELITIAN}

Metode yang dipakai dalam melakukan penelitian ini adalah sebagai berikut:

\section{Metode Pengumpulan Data}

1) Riset Perpustakaan (Library Research)

Yaitu penelitian ini dilakukan dengan cara mempelajari buku-buku, makalahmakalah, artikel-artikel, bacaan laporan-laporan dan publikasi yang berhubungan dengan objek penelitian.

2) Riset Lapangan

Yaitu melakukan penelitian langsung untuk mendapatkan data primer dan sekunder.

\section{Metode Analisis Data}

Dalam menganalisa data, penulis menggunakan metode analisis data kualitatif dan metode kuantitatif. Dimana metode kualitatif menggambarkan, memahami dan menjelaskan data yang diteliti selama penelitian berlangsung. Sedangkan metode kuantitatif menganalisa perhitungan likuiditas pada PT. Bank Perkreditan Rakyat (BPR Batang Kapas.

\section{HASIL DAN PEMBAHASAN}

\section{Bank dan Jenis-jenis bank.}

Bank bersalah dari kata banco yang artinya bangku. Bangku digunakan oleh bankir untuk melayani tanggung jawab operasionalnya kepada para deposan. 
Perbankan adalah suatu lembaga yang memiliki pengaruh dalam perkembangan perekonomian negara terutama bagi negara Indonesia yaitu dalam sektor perindustrian, pertanian dan juga perdagangan. Menurut Undang-Undang RI No.10 Tahun 1998 tentang perbankan, bank merupakan badan usaha yang menampung dana dari masyarakat dalam bentuk simpanan dan menurunkan kembali kepada masyarakat dalam bentuk kredit atau bentuk-bentuk lainnya dalam rangka mengembangkan derajat hidup rakyat banyak.

Sedangkan pengertian bank menurut Irfan dan Faridah (2019) merupakan suatu jenis lembaga finansial yang melakukan berbagai macam jasa, seperti memberi pinjaman, mengedarkan mata uang, pemeriksaan terhadap mata uang, bekerja sebagai tempat penyimpanan benda-benda berharga, membiayai perusahaan-perusahaan dan lain-lain.

\section{Pengertian Laporan Keuangan}

Laporan keuangan pada umumnya yaitu hasil akhir dari sekian banyak transaksi yang terjadi dalam satu perusahaan. Transaksi dan kejadian yang bersifat keuangan dicatat, dihimpun, dan diringkaskan dengan cara setepat-tepanya dalam satuan uang, dan kemudian diadakan penafsiran untuk beragam tujuan. Laporan keuangan yaitu proses akuntansi pada suatu periode tertentu yang adalah hasil pengumpulan data finansial yang disajikan dalam bentuk laporan finansial yang mengacu pada Standar Akuntansi Keuangan (SAK) yang berlaku.

\section{Jenis-jenis Laporan Keuangan}

1. Neraca

Neraca yaitu laporan keuangan yang menentukan posisi keuangan bank pada tanggal tertentu. Posisi keuangan yang berarti ialah aktiva dan pasiva suatu bank.

2. Laporan Komitmen dan Kontijensi

Laporan komitmen dan kontinjensi adalah suatu akad atau kontrak yang berbentuk janji yang tidak bisa ditunda secara sepihak (irrevocable) dan harus dilakukan sesuai dengan kesepakatan bersama.

3. Laporan Laba Rugi

Laporan laba rugi merupakan laporan keuangan bank yang mencerminkan hasil usaha bank dalam suatu periode tertentu.

4. Laporan Arus Kas

Yaitu laporan yang membuktikan semua aspek yang bersangkutan dengan pekerjaan bank, baik yang berpengaruh langsung atau tidak langsung mengenai kas. Laporan arus kas harus disusun menurut konsep kas selama periode laporan.

5. Catatan Atas Laporan Keuangan

Yaitu laporan yang berisi catatan tersendiri mengenai kedudukan devisa neto menurut jenis mata uang dari aktivitas lainnya. 


\section{Laporan Keuangan Gabungan dan Konsolidasi}

Yaitu laporan dari cabang-cabang bank yang bersangkutan, baik yang ada di dalam maupun diluar negeri. Sedangkan laporan keuangan konsolidasi yaitu laporan bank yang bersangkutan dengan anak perusahaan.

\section{Pengertian Likuiditas}

Likuiditas yaitu kemampuan bank untuk menutup kemungkinan ditariknya deposito atau simpanan oleh deposan atau penitip. Dengan kata lain suatu bank dikatakan likuid apabila dapat memenuhi tanggung jawab penarikan uang dari penitip dana maupun dari peminjam atau debitur. Menurut Ramdaniansyah (2020) likuiditas adalah kemampuan sebuah perusahaan dalam memenuhi semua tanggung jawab keuangan yang dapat segera dicairkan atau yang telah jatuh tempo.

\section{Jenis-jenis Alat Likuid}

Jenis alat likuid yang dimiliki oleh bank adalah:

a. Kas atau uang tunai (kertas atau logam) yang tercantum dalam kas bank tersebut.

b. Saldo dana milik bank tersebut, yang terletak pada bank sentral (Saldo Giro $\mathrm{BI})$.

c. Tagihan atau deposito pada bank lain, termasuk bank koresponden.

d. Bank sentral dan Bank koresponden.

\section{Prinsip-prinsip Pengelolaan Likuiditas}

Pengelolaan likuditas harus dilakukan dengan cara hati-hati dengan mengamati prinsip-prinsip yang ada. Oleh karena itu dalam pengelolaan likuiditas bank, perlu diamati beberapa prinsip pengelolaan likuiditas, yaitu:

1. Bank harus mengelola sumber-sumber dana maupun penempatannya dengan tepat sesuai dengan kriteria dana yang dihimpun. Oleh karena itu, harus diamati kualitas sumber dana jatuh tempo menurut jumlah masing-masing komposisi, tingkat suku bunga, faktor kesulitan dalam akumulasi dana, produk dana yang dimiliki dan sebagainya.

2. Bank harus memperhatikan different price for different customer didalam peletakan dananya, dan price (tingkat suku bunga) tersebut harus diatas tingkat suku bunga dana yang digunakannya atau dengan kata lain tingkat suku bunga atas peletakan dana tersebut harus bersifat floating.

3. Bank harus menaruh simpati mengenai sumber dananya bila akan jatuh tempo, jangan sampai terjadi maturity gap dan penempatannya (placement).

4. Bank harus hati-hati bahwa tingkat suku bunga tersebut selalu berfluktuasi, naik turun dengan gerak yang sudah ditebak sebelumnya (volatile). Oleh karena itu, agar bank tidak kekurangan sumber dananya, karena nasabah pindah ke bank lain, maka bank harus menyimpan pricing policy yang baik, disampingnya itu harus mempunyai strategi yang minimal mencakup strategi di produk, kekuatan dan hubungan. 


\section{Tujuan dan Manfaat Pengelolaan Likuiditas}

1. Untuk menaksir kemampuan bank dalam memenuhi semua kewajiban atau hutang yang segera jatuh tempo pada saat ditagih, artinya kemampuan untuk menutup kewajiban yang sudah waktunya dibayar sesuai batas waktu yang telah disepakati.

2. Untuk menaksir kemampuan bank menutup kewajiban jangka pendek dengan aktiva lancar secara keseluruhan, artinya jumlah kewajiban lancar dibandingkan dengan total aktiva lancar.

3. Untuk memperkirakan seberapa besar uang kas yang tersedia untuk membayar hutang.

4. Sebagai alat persiapan kedepan, terutama yang berkaitan dengan persiapan kas dan hutang.

5. Untuk mengamati kondisi dan posisi likuiditas bank dari waktu ke waktu dalam membandingkannya untuk beberapa periode.

6. Untuk mengamati kelemahan yang dimiliki perusahaan, dari masing-masing komponen yang ada di aktiva lancar dan hutang lancar.

7. Merupakan alat pemicu bagi pihak manajemen untuk menyesuaikan kinerjanya, dengan mengamati rasio likuiditas yang ada pada saat ini.

8. Untuk mengetahui apakah bank memiliki masalah dalam penghimpunan dan penyaluran dananya.

\section{Tingkat Kesulitan dalam Pengelolaan Likuiditas}

Menurut Afriyeni dan Mardila (2019) Kesulitan yang timbul dalam pengelolaan likuiditas dapat dikelompokkasn menjadi 2 jenis, yaitu:

1. Kesulitan Likuiditas Temporer

Kesulitan likuiditas temporer dimana bank tersebut masih memiliki likuiditas yang cukup untuk memenuhi kebutuhan operasional hariannya. Kesulitan tersebut belum berakibat fatal, kesulitan tersebut bias diakibatkan karena penerimaan, sebagai akibat dari telah terjadi cut off time pada Bank Sentral, sehingga untuk kebutuhan kas atau giro pada Bank Indonesia saat itu saldonya menjadi tidak cukup atau negative.

2. Kesulitan Likuiditas Struktural

Kesulitan tersebut timbulnya karena adanya mismatch yang lebih lama dibandingkan dengan kesulitan likuiditas temporer, umumnya disebabkan karena pemberian kredit yang jangka waktunya tidak sesuai denga jangka waktu tersedianya suimber dana.

\section{Analisis}

a. Cash Ratio (CR)

Cash Ratio yaitu rasio likuid mengenai dana pihak ketiga yang dihimpun bank yang segera dibayar. Rasio ini dipergunakan untuk menilai kemampuan bank dalam melunasi kembali simpanan nasabah (deposan) pada saat ditarik dengan memerlukan alat likuid yang dimilikinya. 


\section{Tabel 1}

Perkembangan Cash Ratio Tahun 2017-2019

(Dalam Rupiah)

\begin{tabular}{lccc}
\hline \multicolumn{1}{c}{ Uraian } & $\mathbf{2 0 1 7}$ & $\mathbf{2 0 1 8}$ & $\mathbf{2 0 1 9}$ \\
\hline Alat likuid & & & \\
a. Kas & 711.632 .528 & 751.324 .242 & 360.970 .374 \\
b. Antar Bank & 7.653 .662 .221 & 8.111 .435 .863 & 6.298 .586 .608 \\
$\quad$ Aktiva & & & \\
Jumlah & 8.365 .294 .749 & 8.862 .760 .105 & 6.659 .556 .982 \\
Hutang Lancar & & & \\
$\quad$ a. Kewajiban & 43.762 .641 & 34.382 .678 & 55.855 .533 \\
$\quad$ Segera & 8.036 .561 .597 & 8.625 .744 .443 & 8.897 .436 .143 \\
b. Tabungan & 16.994 .000 .000 & 18.373 .000 .000 & 18.974 .500 .000 \\
c. Deposito & 25.074 .324 .238 & 27.033 .127 .121 & 27.927 .791 .676 \\
Jumlah & & & \\
\hline
\end{tabular}

Sumber: Laporan Keuangan PT. BPR Batang Kapas

b. Quick Ratio (QR)

Quick Ratio (Rasio Cepat) menggambarkan rasio membuktikan kebijakan perusahaan dalam melunasi tanggung jawab atau utang lancar dengan aktiva lancar tanpa memperhitungkan persediaan Sanjaya dan Marlius (2017).

\section{Tabel 2}

Perkembangan Quick Ratio Tahun 2017-2019

(Dalam Rupiah)

\begin{tabular}{cccc}
\hline Uraian & $\mathbf{2 0 1 7}$ & $\mathbf{2 0 1 8}$ & $\mathbf{2 0 1 9}$ \\
\hline Alat Likuid: & & & \\
Kas & 711.632 .528 & 751.324 .242 & 360.970 .374 \\
Hutang Lancar & 43.762 .641 & 34.382 .679 & 55.855 .533 \\
\hline
\end{tabular}

Sumber: Laporan Keuangan PT. BPR Batang Kapas

c. Loan to Deposit Ratio (LDR)

Loan to Deposit Ratio yaitu kebijakan bank dalam melunasi kembali dana penarikan yang telah dilakukan oleh deposan dengan menggunakan kredit yang diberikan bank dengan dana yang diterima oleh bank. 
Tabel 3

Perkembangan Loan to Deposit Ratio Tahun 2017-2019 (Dalam Rupiah)

\begin{tabular}{|c|c|c|c|}
\hline Uraian & 2017 & 2018 & 2019 \\
\hline $\begin{array}{ll}\text { a. } & \text { Kredit } \\
\text { Yang } \\
\text { Diberikan }\end{array}$ & 22.518 .383 .159 & 24.453 .145 .177 & 28.351 .645 .299 \\
\hline b. DPK & 8.036 .561 .597 & 8.625 .744 .443 & 8.897 .436 .143 \\
\hline Tabungan & 16.994 .000 .000 & 18.373 .000 .000 & 18.974.500.000 \\
\hline $\begin{array}{l}\text { Deposito } \\
\text { Modal }\end{array}$ & 4.055 .000 .000 & 4.754 .000 .000 & 5.177 .000 .000 \\
\hline
\end{tabular}

Sumber: Laporan Keuangan PT. BPR Batang Kapas

\section{PEMBAHASAN}

Perkembangan Cash Ratio pada PT. Bank Perkreditan Rakyat Batang Kapas dalam 3 (tiga) tahun ini menunjukkan kecenderungan yang berfluktuasi. Pada tahun 2017, Cash Ratio menunjukkan angka sebesar 33,36\%, dan mengalami penurunan pada tahun 2018 sampai 2019, pada tahun 2018 mengalami penurunan menjadi $32,78 \%$, dan pada tahun $201923,84 \%$.

Dari uraian diatas, dapat dilihat bahwa nilai Cash Ratio pada PT. Bank Perkreditan Rakyat Batang Kapas dari tahun 2017 sampai tahun 2019 tergolong sehat karena besar dari 4,05\%, yang nilainya berkisar dari 33,36\% sampai 23,84\%, yang berarti Cash Ratio PT. Bank Perkreditan Rakyat Batang Kapas dalam beberapa periode tersebut berada diatas nilai standar yang ditetapkan oleh Bank Indonesia. Perkembangan Quick Ratio pada PT. Bank Perkreditan Rakyat Batang Kapas dalam 3 (tiga) tahun membuktikan pada tahun 2017 menunjukkan angka sebesar 1.626,11\% dan mengalami peningkatan pada tahun 2018 menjadi 2.185,18\%. Dari uraian diatas, dapat dilihat bahwa nilai Quick Ratio pada PT. Bank Perkreditan Rakyat Batang Kapas dari tahun 2017 sampai tahun 2019 tergolong sehat, karena berada pada posisi $<100 \%$.

Perkembangan Loan to Deposit Ratio pada PT. Bank Perkreditan Rakyat Batang Kapas dalam 3 (tiga) tahun ini menunjukkan Pada tahun 2017 nilai Loan to Deposit Ratio menunjukkan angka sebesar 77,42\%. Pada tahun 2018 sebesar 77,01\%. Sedangkan pada tahun 2019 sebesar 86\%. Dari uraian diatas, dapat dilihat nilai ratarata Loan to Deposit Ratio PT. Bank Perkreditan Rakyat Batang Kapas dari tahun 2017 sampai tahun 2018 berada pada posis 75\% < LDR $\leq 85 \%$ dalam kriteria sehat. Dan pada tahun 2019 kriteria penilaian LDR cukup sehat, karena berada pada posisi $85 \%<$ LDR $\leq 100 \%$.

\section{SIMPULAN}

Berdasarkan uraian penjelasan tentang analisis rasio likuiditas pada hasil dan pembahasan yang dikemukakan pada bab sebelumnya, maka dapat disimpulkan 
analisis laporan keuangan pada PT. BPR Batang Kapas dilihat dari rasio likuiditas adalah sebagai berikut:

1. Secara umum keadaan keuangan PT. BPR Batang Kapas tahun 2017-2019 berdasarkan pengukuran rasio likuiditasnya dalam keadaan likuid.

2. Keadaan keuangan pada PT. BPR Batang Kapas jika berdasarkan hasil pengukuran Cash Ratio dalam keadaan sehat. Hal ini terlihat pada nilai Cash Ratio pada tahun 2017-2019 berkisar antara 23,84\%-33,36\%, nilai ini tergolong sehat walaupun berada diatas nilai yang ditetapkan oleh standar Bank Indonesia yang dimana $>=4,05 \%$ dikatakan sehat.

3. Keadaan keuangan pada PT. BPR Batang Kapas jika berdasarkan hasil pengukuran Quick Ratio dalam keadaan sehat. Dilihat dari hasil penilaian Quick Ratio pada tahun 2017-2019 berkisar antara 646,25\%-2.185,18\%, nilai ini tergolong baik karena berada diatas $100 \%$. Semakin besar rasio, semakin baik juga posisi keuangan.

4. Keadaan keuangan pada PT. Bank Perkreditan Rakyat Batang Kapas dari tahun 2017 sampai tahun 2019 jika berdasarkan hasil pengukuran Loan to Deposit Ratio dalam keadaan sehat. Hal ini terlihat dari hasil pengukuran Loan to Deposit Ratio dari ketiga tahun.

\section{UCAPAN TERIMA KASIH}

Penulis mengucapkan terima kasijh kepada PT. BPR Batang Kapas yang telah mengizinkan dan membantu dalam memperoleh informasi. Serta semua pihak yang telah membantu dalam penyelesaian penelitian ini.

\section{DAFTAR PUSTAKA}

Adlia Soma, Dewi. 2018. "analisis laporan keuangan untuk menilai kinerja keuangan pada PT. kimia farma Tbk periode 2012-2016." Jurnal Ilmu dan Riset Manajemen 7(1).

Arifin, I. Z., \& Marlius, D. (2017). Analisis Kinerja Keuangan PT. Pegadaian Cabang Ulak Karang. https://doi.org/10.31227/osf.io/n2peu

Badria, M., \& Marlius, D. (2019). Analisis Rasio Likuiditas Pada PT. Bank Perkreditan Rakyat (BPR) Lengayang. https://doi.org/10.31219/osf.io/esvb7

Eviani, Dewi Anantia. 2015. "pengaruh struktur aktiva, pertumbuhan penjualan, dividend payout ratio, likuiditas dan profitabilitas terhadap struktur modal." Akuntansi dan Sistem Teknologi Informasi 11(2): 194-202.

Fitri, H. Y., \& Marlius, D. (2019). Analisis Rasio Likuiditas Pada PT. Bank Perkreditan Rakyat (BPR) Nagari Kasang. https://doi.org/10.31219/osf.io/bcs73

Handayani, M., \& Marlius, D. (2017). Analisis Tingkat Kesehatan PT. BPR Batang Kapas. https://doi.org/10.31227/osf.io/bq48z

Irfan, dan Cut Faridah. 2019. "pengaruh tingkat suku bunga deposito dan jumlah nasabah terhadap jumlah dana deposito berjangka pada pt bank negara indonesia ( persero ) tbk cabang lhokseumawe." Akuntansi dan Pembangunan | 5(1): 41-48. 
Mardila, W., \& Afriyeni, A. (2019). Analisis Laporan Keuangan Berdasarkan Likuiditas Pada PT Bank Pembangunan Daerah Sumatera Barat Cabang Utama. https://doi.org/10.31219/osf.io/cjkbt

Marlius, D., \& Sukma, J. (2020). Analisis Tingkat Kesehatan Bank Pt. Bank Perkreditan Rakyat Jorong Kampung Tangah Pariaman Cabang Padang. https://doi.org/10.31219/osf.io/dmjy5

Mustika, S., \& Marlius, D. (2019). Analisa Tingkat Kesehatan Keuangan PT. Bank Perkreditan Rakyat (BPR) Batang Palangki. https://doi.org/10.31219/osf.io/wupyh

Rahmayeli, D. S., \& Marlius, D. (2017). Analisis Kinerja Keuangan Pada PT. Bank Perkreditan Rakyat (BPR) Batang Kapas Pesisir Selatan. https://doi.org/10.31227/osf.io/sz5db

Ramdaniansyah, Muhammad Rizky. 2020. "Pengaruh Likuiditas dan Solvabilitas terhadap Profitabilitas pada PT . Indofood CBP Sukses Makmur tbk . Yang terdaftar di Bursa Efek Indonesia." riset akuntansi dan keuangan 2(1): 1-7.

Shanjaya, A. R., \& Marlius, D. (2017). Peranan Laporan Keuangan Dalam Kebijaksanaan Pemberian Kredit Kepada Calon Nasabah Pada PT. BPR Batang Kapas. https://doi.org/10.31227/osf.io/uxmg6. 